\title{
FokI and BsmI Polymorphisms of the VDR Gene and Breast Cancer Risk
}

\author{
Sasan Talaneh ${ }^{1}$, Abolfazl Ghorbani ${ }^{2, *}$, Tayebe Oghabi Bakhshaiesh ${ }^{3}$, \\ Behbuod Jafari ${ }^{4}$ \\ ${ }^{1}$ Department of Basic Sciences, Islamic Azad University, Ahar Branch, Ahar, Iran \\ ${ }^{2}$ Department of Animal Science, Islamic Azad University, Shabestar Branch, \\ Shabestar, Iran \\ ${ }^{3}$ Department of Medical Biotechnology, Faculty of Advanced Medical Sciences, Tabriz \\ University of Medical Sciences, Tabriz, Iran \\ ${ }^{4}$ Department of Microbiology, Islamic Azad University, Ahar Branch, Ahar, Iran \\ * Corresponding author: Abolfazl Ghorbani, Department of Animal Science, Islam- \\ ic Azad University, Shabestar Branch, Shabestar, Iran.E-mail: Abolfazlgorbani@ \\ gmail.com
}

DOI: $10.21859 / \mathrm{mci}-01018$

Submitted: 5 April 2016

Revised: 1 August 2016

Accepted: 24 August 2016

ePublished: 08 September 2016

Keywords:

Breast Cancer

Calcitriol Receptors

Polymorphism

RFLP

\begin{abstract}
Introduction: Vitamin D fulfills its crucial role in cell proliferation and death through signal transduction into the nucleus by vitamin D receptor (VDR). Recent studies have depicted the association between VDR gene polymorphisms and different cancers, including breast cancer. This study attempted to consider the relationship between VDR gene polymorphisms and breast cancer risk among women in West Azerbaijan Province, Iran.

Methods: FokI and BsmI polymorphisms were studied through the polymerase chain reaction-restriction fragment length polymorphism (PCR-RFLP) technique on blood samples taken from 95 cancer and 71 healthy participants from Urmia City. The association between the mentioned polymorphisms and breast cancer risk was considered using calculated odds ratio (OR).

Results: The findings showed the protective effect of the FokI polymorphism in breast cancer development $(\mathrm{OR}=0.2731)$, while no statistically significant correlation was observed between breast cancer and BsmI polymorphism $(\mathrm{P}>0.05)$.

Conclusions: This study identified the protective effect of the FokI polymorphism in breast cancer, and the absence of statistically significant association between BsmI polymorphism and breast cancer.
\end{abstract}

(C) 2016. Multidisciplinary Cancer Investigation

\section{INTRODUCTION}

Breast cancer is considered to be the most common cancer among women in the world, and accounts for $24.4 \%$ of total cases of cancer in Iran [1]. In Iran, the age of onset for breast cancer ( 45 to 55 years in average) is about 10 years less than developed countries ( 55 to 65 years) [2]. Despite huge progresses in breast cancer diagnosis and treatment, it still remains a major challenge due to its late diagnosis and lack of a definitive treatment.

Vitamin $\mathrm{D}$ is a fat-soluble vitamin that performs its biological role in the body through its bioactive form (1, 25-dihydroxyvitamin D). Vitamin D insufficiency is associated with different diseases including cancer [3]. Research on cell lines and animal models has pointed toward the inhibitory effect of vitamin $\mathrm{D}$ on breast tumors incidence and metastasis [4].
The interaction between Vitamin $\mathrm{D}$ and its receptor is necessary for its activity in cells. Vitamin D receptor (VDR) belongs to the large family of steroid receptors expressed in various tissues, including breast cells [4]. It transduces signals from the vitamin $\mathrm{D}$ cycle to the cell nucleus, which can affect the expression of some genes $[5,6]$. Some studies have shown that breast cancer cells express lower levels of $V D R$ than normal cells. Zinser et al. showed that $V D R$ inactivity causes breast tumors in mice [7]. The level of $V D R$ could diminish due to several reasons, such as polymorphisms of the VDR gene [5], which has a number of important single nucleotide polymorphisms (SNP). The most common SNPs of the VDR gene tested among different populations were rs2228570 and rs1544410, which are cut by the FokI and BsmI restriction enzymes, respectively. The Rs1544410 resides in intron 8, near the 
3'UTR, and rs2228570 is located in the 5' promoter region of the VDR gene $[4,8,9]$. Analyses have established an association between FokI, the 3'UTR region polymorphisms and breast cancer risk [10].

The association between different VDR SNPs and breast cancer has been studied in a number of populations. However, their findings require to be further processed in order to clarify the role of different VDR polymorphisms in breast cancer risk. In this way, the present study examined FokI and BsmI polymorphisms for their impact on breast cancer occurrence among a group of women in Urmia City, Iran.

\section{METHODS}

\section{Moral approval}

This research was conducted after receiving a moral approval from the Ethics Committee of the Medical Faculty, Urmia University. The participants in the study also completed and signed an informed consent.

\section{Research population}

The study included 166 participants, divided to one patients group (95 patients from Omid Hospital in Urmia City) and one control group (71 person from Shahid Motahari Hospital in Urmia City). The control group comprised of women, whose initial clinical examinations did not show any breast tumors. The participants were selected from women, who had not been taking vitamin $\mathrm{D}$ on a regular basis.

The participants' information, including age, body mass index (BMI), number of pregnancies, pregnancy age, breast-feeding age, use of oral contraceptive pills (OCP) and menopause age, was collected from their medical records. Some of the healthy participants did not refer to the hospital during the study and their results were not complete and thus were omitted from the analysis.

\section{DNA extraction}

Genomic DNA of participants was extracted from 4 cc of whole blood samples, using the improved phenol-chloroform method (Barzegar et al.). Agarose gel $(0.7 \%)$ was also employed to determine the quality and quantity of the extracted DNA, and the SNPs were iden- tified through the Polymerase Chain Reaction-Restriction Fragment Length Polymorphism (PCR-RFLP) technique [11]. The exon 2 segment related to the FokI, and the intron 8 segment targeted by BsmI were proliferated by the PCR, using special primers (Table 1 ).

PCR was conducted under the following conditions: denaturation at $94^{\circ} \mathrm{C}$ for five minutes, followed by 40 cycles at $94^{\circ} \mathrm{C}$ (for 30 seconds), $61^{\circ} \mathrm{C}$ (for 30 seconds) and $72^{\circ} \mathrm{C}$ (for 30 seconds).

The PCR products were digested by FokI and BsmI enzymes and in accordance with the enzyme manufacturer's protocol (Fermentas from Vilnius, Lithuania). The presence or absence of enzyme restriction sites was shown with Safe Stain on Agarose gel (2\%). Each test was repeated at least for three times.

FokI and BsmI alleles were marked with capitals letters ( $\mathrm{F}$ $=\mathrm{C}$ and $\mathrm{B}=\mathrm{A}$, respectively) for the absence of enzyme restriction sites, and with small letters $(\mathrm{f}=\mathrm{T}$ and $\mathrm{b}=\mathrm{G}$, respectively) for the presence of enzyme restriction sites.

\section{Statistical analysis}

The data was analyzed by the SPSS18, and the genotypic and allelic frequencies were determined by Pop Gene Slope and the Hardy-Weinberg Equilibrium test. In order to determine the correlation between the polymorphisms and breast cancer incidence, the odds ratio (OR) and the corresponding 95\% confidence intervals were calculated.

\section{RESULTS}

\section{Association Between VDR Gene SNPs and Breast Cancer Risk}

The FokI enzyme digested 168 base pair segments and resulted in the three groups; FF homozygous genotypes with 168 base pairs, Ff homozygous genotypes with 168,140 and 28 base pairs, and ff genotypes with 140 and 28 base pairs.

The frequency of various genotypes of the population depicted that the ff genotype (with a frequency of $81.9 \%$ ) and the $f$ allele (with a frequency of $85.1 \%$ ) were the most common among the participants in this study. Moreover, the chi-square of 90.07 meant the population was not in the Hardy-Weinberg equilibrium (Table 2).

Table 1: Primer Sequences

\begin{tabular}{lc}
\hline \multicolumn{1}{|c|}{ Exon $\mathbf{2}$} & Primers \\
\hline FokI (46559145-46559162) & \\
\hline & F: 5'-TGGCCGCCATTGCCTCCG-3' \\
\hline Intron 8 & R: 3'-CGGAGGCAATGGCGGCCA-5' \\
\hline BsmI (46526083-46526102) & \\
\hline & F: 5'-AGCCTGAGTACTGGGAATGT-3' \\
\hline
\end{tabular}


Table 2: Allelic and Genotypic Frequency, Along With Chi-Square for the Hardy-Weinberg Equilibrium After Enzyme Digestion of 168 base pair Segments by the FokI Enzyme

\begin{tabular}{lccccc}
\hline Observed Allele & Chi-Square & Expected & Observed & Value & Genotype \\
\hline $\mathrm{F}=0.147$ & & 0.021 & 0.114 & 19 & $\mathrm{FF}$ \\
$\mathrm{f}=0.85$ & 90.07 & 0.0251 & 0.066 & 11 & $\mathrm{Ff}$ \\
\hline
\end{tabular}

Table 3: Genotypic Frequencies Related to FokI Polymorphism

\begin{tabular}{lcccc}
\hline Genotypes & Cases $(\mathbf{n}=\mathbf{9 5})$, No. $(\%)$ & Controls $(\mathbf{n}=\mathbf{7 1})$, No. $(\%)$ & OR, $(\mathbf{9 5 \%} \mathbf{C I})$ & P Value \\
\hline FF & $16(16.8)$ & $3(4.2)$ & 1 (Reference) & \\
Ff & $8(8.4)$ & $3(4.2)$ & $0.5000(0.081-3.05)$ & 0.4533 \\
ff & $71(74.7)$ & $65(91.5)$ & $0.2731(0.057-0.735)$ & 0.0078 \\
\hline
\end{tabular}

Table 4: Allelic and Genotypic Frequency, Along With Chi-Square for the Hardy-Weinberg Equilibrium After Enzyme Digestion of 823 Base Pair Segments by the BsmI Enzyme

\begin{tabular}{lccccc}
\hline Observed Allele & Chi-Square & Expected & Observed & Value & Genotype \\
\hline $\mathrm{A}=0.127$ & & 0.160 & 0.663 & 11 & $\mathrm{BB}$ \\
& 34.34 & 0.221 & 0.120 & 20 & $\mathrm{Bb}$ \\
$\mathrm{G}=0.873$ & & 0.763 & 0.813 & 135 & $\mathrm{bb}$ \\
\hline
\end{tabular}

Table 5: Genotypic Frequencies Related to BsmI Polymorphism

\begin{tabular}{lcccc}
\hline Genotypes & Cases $(\mathbf{n}=\mathbf{9 5})$, No. $(\%)$ & Controls $(\mathbf{n}=\mathbf{7 1})$, No. $(\%)$ & OR, (95\% CI) & P Value \\
\hline $\mathrm{BB}$ & $10(10.5)$ & $1(1.4)$ & 1 (Reference) & \\
$\mathrm{Bb}$ & $12(12.6)$ & $8(11.2)$ & $0.15(0.0159-1.411)$ & 0.0972 \\
$\mathrm{bb}$ & $73(76.8)$ & $62(87.3)$ & $0.11(0.014-0.945)$ & 0.0906 \\
\hline
\end{tabular}

\section{Equilibrium After Enzyme Digestion of 168 Base Pair Segments by the FokI Enzyme}

Table 3 depicts the distribution of VDR-FokI polymorphisms in the patient and control groups. The OR assessments by comparing FF and ff genotypes pointed toward the protective role of the ff genotype against breast cancer incidence.

Three genotypes of BB with 823 base pairs, bb with 177 and 646 base pairs, and the heterozygous $\mathrm{Bb}$ with 823 , 646 and 177 base pairs were observed and categorized after enzyme digestion of PCR products with the BsmI enzyme.

The results also identified $b$ allele with $87.3 \%$ and $B$ allele with $12.7 \%$ to possess the highest and lowest frequencies, respectively. A comparison of observed and expected frequencies attested that the population was not in the Hardy-Weinberg equilibrium (Table 4).

Table 5 depicts the distribution of VDR-BsmI polymorphisms in the patient and control groups. The calculated $\mathrm{P}$ $>0.05$ for the $\mathrm{bb}$ genotype, compared to the $\mathrm{BB}$ genotype meant that BsmI polymorphism had no relationship with breast cancer in the population under study.

\section{DISCUSSION}

Several studies have considered the association be- tween vitamin D and cancers, especially in the recent years. Research on various populations has pointed toward the impact of low vitamin D levels and breast cancer risk $[12,13]$. Researchers have also identified a positive relationship between the gene polymorphisms, which are associated with vitamin $\mathrm{D}$ performance and breast cancer occurrence. According to these studies, different polymorphisms in the VDR gene have been identified to affect the risk of the breast cancer [14]. The presence of the restriction site of FokI enzyme on the VDR gene $(f$ allele $=T)$ produces a protein that performs less efficiently than the natural protein [8]. The present study compared two healthy and cancerous groups, and established that the presence of the VDR polymorphism would play a protective role against breast cancer incidence. A research by Ingles et al. on allelic variation located at or near the 3' end of the VDR gene, as well as the FokI polymorphism located at the 5 ' end of this gene depicted a correlation of the BsmI polymorphism and other polymorphisms at the poly (A) tail, with breast cancer risk. According to this study, no correlation was observed between the start codon polymorphism (FokI) and the risk of breast cancer incidence [15]. Another study by McKay et al. on 405 women with breast cancer in comparison with 405 healthy women in a Japanese-American population 
reported that ff genotype is related to breast cancer occurrence [16]. However, studies on a group of women affected by breast cancer in China and Iran failed to report a similar relationship between the FokI polymorphism and breast cancer risk $[17,18]$.

The BsmI polymorphism in intron 8 region of the $V D R$ gene changes the stability of VDR mRNA, and subsequently, the VDR protein levels [8]. Several studies have concentrated on the association between this polymorphism and breast cancer, which have shown various outcomes. Some reported that BB genotype (no enzyme restriction site) correlates whit occurrence risk, while others identified the presence of polymorphisms and the bb genotype as a factor increasing the risk. In a study by Lowe et al., it was concluded that a low level of vitamin $\mathrm{D}$ in plasma and/or along with the BsmI polymorphisms of the VDR gene could heighten the risk of breast cancer incidence [19]. The present study identified no significant association between the BsmI polymorphism and breast cancer risk in the participating population. Similarly, studies on Chinese and Pakistani women with breast cancer did not observe any relationship between the mentioned factors [4]. That is while a study on a population of Iranian women reported a correlation between the presence of the restriction site ( $b$ allele) and breast cancer occurrence $[18]$. Furthermore, a research on the previously mentioned Japanese-American population confirmed the decrease of breast cancer risk by the presence of allele $\mathrm{B}[16]$.

The discrepancies observed in the results of the mentioned studies could be attributed to the differences in the number of participants, their races and the impact of factors not simultaneously considered in those cases. On the other hand, studies in the recent years have pointed toward the association between concentration of vitamin D and breast cancer [19]. Confirming the role of vitamin $\mathrm{D}$ in preventing breast cancer, and the development of a novel treatment method definitely requires further investigations on different polymorphisms of the VDR gene, and simultaneous consideration of the presence of these polymorphisms along with other factors, including genetic factors (such as mutation in BRCA1/2 genes) and environmental factors (the nutritional diet and vitamin $\mathrm{D}$ concentrations in the participants' bodies, etc.).

\section{ACKNOWLEDGMENT}

The authors would like to express their gratitude to the personnel of Islamic Azad University of Ahar, Omid and Shahid Motahari Hospitals.

\section{CONFLICT OF INTEREST}

The authors declared that there was no conflict of interests.

\section{REFERENCES}

1. Siegel R, Naishadham D, Jemal A. Cancer statistics, 2013. CA Cancer J Clin. 2013;63(1):11-30. DOI: 10.3322/caac.21166 PMID: 23335087

2. Mousavi SM, Montazeri A, Mohagheghi MA, Jarrahi AM, Harirchi I, Najafi M, et al. Breast cancer in Iran: an epidemiolog ical review. Breast J. 2007;13(4):383-91. DOI: 10.1111/j.1524 4741.2007.00446.x PMID: 17593043

3. Hou W, Wan X, Fan J. Variants Fok1 and Bsm1 on VDR are associated with the melanoma risk: evidence from the published epidemiological studies. BMC Genet. 2015;16:14. DOI: 10.1186/s12863-015-0163-6 PMID: 25887475

4. Rashid MU, Muzaffar M, Khan FA, Kabisch M, Muhammad N, Faiz S, et al. Association between the BsmI Polymorphism in the Vitamin D Receptor Gene and Breast Cancer Risk: Results from a Pakistani Case-Control Study. PLoS One. 2015;10(10):e0141562. DOI: 10.1371/journal.pone.0141562 PMID: 26517870

5. Feldman D, Krishnan AV, Swami S, Giovannucci E, Feldman BJ. The role of vitamin $\mathrm{D}$ in reducing cancer risk and progression. Nat Rev Cancer. 2014;14(5):342-57. DOI: 10.1038/nrc3691 PMID: 24705652

6. Chen H, Reed G, Guardia J, Lakhan S, Couture O, Hays E, et al. Vitamin D directly regulates $\mathrm{Mdm} 2$ gene expression in osteoblasts. Biochem Biophys Res Commun. 2013;430(1):370-4. DOI: 10.1016/j.bbrc.2012.11.003 PMID: 23149414

7. Zinser GM, Suckow M, Welsh J. Vitamin D receptor (VDR) ablation alters carcinogen-induced tumorigenesis in mammary gland, epidermis and lymphoid tissues. J Steroid Biochem Mol Biol. 2005;97(1-2):153-64. DOI: 10.1016/i jsbmb.2005.06.024 PMID: 16111884

8. Sinotte M, Rousseau F, Ayotte P, Dewailly E, Diorio C, Giguere $\mathrm{Y}$, et al. Vitamin D receptor polymorphisms (FokI, BsmI) and breast cancer risk: association replication in two case-control studies within French Canadian population. Endocr Relat Cancer. 2008;15(4):975-83. DOI: 10.1677/ERC-08-0056 PMID $\underline{18719092}$

9. Osman E, Al Anouti F, El Ghazali G, Haq A, Mirgani R, Al Safar H. Frequency of rs731236 (Taql), rs2228570 (Fok1) of Vitamin-D Receptor (VDR) gene in Emirati healthy population. Meta Gene. 2015;6:49-52. DOI: 10.1016/j.mgene.2015.09.001 PMID: 26504744

10. 10. Uitterlinden AG, Fang Y, Van Meurs JB, Pols HA, Van Leeuwen JP. Genetics and biology of vitamin D receptor polymorphisms. Gene. 2004;338(2):143-56. DOI: 10.1016/i. gene.2004.05.014 PMID: 15315818

11. Ota M, Fukushima H, Kulski JK, Inoko H. Single nucleotide polymorphism detection by polymerase chain reaction-restriction fragment length polymorphism. Nat Protoc. 2007;2(11):2857-64. DOI: 10.1038/nprot.2007.407 PMID 18007620

12. Yang B, Liu S, Yang X, Wang Y, Zhao X, Zheng D, et al. Current evidence on the four polymorphisms of VDR and breast cancer risk in Caucasian women. Meta Gene. 2014;2:41-9. DOI: 10.1016/j.mgene.2013.09.008 PMID: 25606388

13. Chen P, Hu P, Xie D, Qin Y, Wang F, Wang H. Meta-analysis of vitamin $\mathrm{D}$, calcium and the prevention of breast cancer Breast Cancer Res Treat. 2010;121(2):469-77. DOI: 10.1007/ s10549-009-0593-9 PMID: 19851861

14. Yao S, Ambrosone CB. Associations between vitamin $\mathrm{D}$ deficiency and risk of aggressive breast cancer in African-American women. J Steroid Biochem Mol Biol. 2013;136:337-41. DOI: 10.1016/i.jsbmb.2012.09.010 PMID: 22995734

15. Ingles SA, Garcia DG, Wang W, Nieters A, Henderson BE, Kolonel LN, et al. Vitamin D receptor genotype and breast cancer in Latinas (United States). Cancer Causes Control. 2000;11(1):25-30. PMID: 10680726

16. McKay JD, McCullough ML, Ziegler RG, Kraft P, Saltzman BS Riboli E, et al. Vitamin D receptor polymorphisms and breast cancer risk: results from the National Cancer Institute Breast and Prostate Cancer Cohort Consortium. Cancer Epidemiol Biomarkers Prev. 2009;18(1):297-305.

17. Dorjgochoo T, Delahanty R, Lu W, Long J, Cai Q, Zheng Y, et al. Common genetic variants in the vitamin $\mathrm{D}$ pathway includ- 
ing genome-wide associated variants are not associated with breast cancer risk among Chinese women. Cancer Epidemiol Biomarkers Prev. 2011;20(10):2313-6.

18. Shahbazi S, Alavi S, Majidzadeh AK, Ghaffarpour M, Soleimani A, Mahdian R. BsmI but not FokI polymorphism of VDR gene is contributed in breast cancer. Med Oncol. 2013;30(1):393.
DOI: $10.1007 / \mathrm{s} 12032-012-0393-7$ PMID: 23277283

19. Lowe LC, Guy M, Mansi JL, Peckitt C, Bliss J, Wilson RG, et al. Plasma 25-hydroxy vitamin D concentrations, vitamin D receptor genotype and breast cancer risk in a UK Caucasian population. Eur J Cancer. 2005;41(8):1164-9. DOI: 10.1016/j. ejca.2005.01.017 PMID: 15911240 